\title{
Система інтегративної кінезитерапії як сучасний метод фізичної реабілітації при захворюваннях опорно-рухової системи
}

\author{
УДК 616.7-089.2:615.825ЛФК
}

\section{Б. М. Кравченко}

Медичний центр кінезитерапії «КінезісЛайф», Київ, Україна

\begin{abstract}
Резюме. Представлено Систему інтегративної кінезитерапії як новий немедикаментозний холістичний підхід до відновлення здоров'я, реабілітації та профілактики захворювань опорно-рухової системи. Вона базується на синтезі кінезіологічної діагностики, корекції та кінезитерапії. Інтегративний підхід забезпечує вплив не лише на проблемну зону, а й на весь організм у цілому і дає можливість проводити відновну терапію причини захворювання, а не ії наслідків. За допомогою мануального м'язового тестування визначаються причина патології та методи їі корекції. За результатами тестування й корекції розробляється кінезитерапевтична програма, яка забезпечує активізацію внутрішніх регенераційних і відновних процесів в організмі людини шляхом виконання фізичних вправ. Крім цього, Система дозволяє виявити приховані рухові резерви організму, наприклад спортсмена, і запропонувати механізми перенавчання з метою оптимізації виконуваних професійних рухів.
\end{abstract}

Ключові слова: кінезитерапія, кінезіологія, діагностика, корекція, реабілітація, стереотип, м'язи, тестування, здоров'я.

Резюме. Представлено Систему интегративной кинезитерапии как новый немедикаментозный холистический подход к восстановлению здоровья, реабилитации и профилактике заболеваний костно-мышечной системы. Она базируется на синтезе кинезиологической диагностики, коррекции и кинезитерапии. Интегративный подход обеспечивает влияние не только на проблемную зону, но и на весь организм в целом и позволяет проводить восстановительную терапию причины заболевания, а не его последствий. С помощью мануального мышечного тестирования определяются причина патологии и методы ее коррекции. По результатам тестирования и коррекции разрабатывается кинезитерапевтическая программа, которая обеспечивает активизацию внутренних регенерационных и восстановительных процессов в организме человека путем выполнения физических упражнений. Кроме этого, система позволяет выявить скрытые двигательные резервы организма, например спортсмена, и предложить механизмы переобучения с целью оптимизации выполняемых профессиональных движений. Ключевые слова: кинезитерапия, кинезиология, диагностика, коррекция, реабилитация, стереотип, мышцы, тестирование, здоровье.

Abstract. The system of integrative kinesitherapy as a new drug-free holistic approach to health recovery, rehabilitation and prevention of diseases of musculoskeletal system has been presented. It is based on a synthesis of kinesiological diagnostics, correction and kinesitherapy. Integrative approach provides an impact not only on one problem area, but on the whole body as well and allows to use the replacement therapy of the disease cause rather than its consequences. By means of manual muscle testing the cause of pathology and methods of its correction may be determined. According to testing and correction results, kinesitherapy program is developed that provides recovery 
and activation of internal regeneration and recovery processes in human body through physical exercises. In addition, the system allows to reveal the hidden motor reserves of the body, for instance, of an athlete and offer retraining mechanisms to optimize execution of professional movements.

Keywords: kinesitherapy, kinesiology, diagnostics, correction, rehabilitation, stereotype, muscles, testing, health.

Вступ. В умовах зростання несприятливих екологічних умов та інших негативних чинників зовнішнього середовища, що впливають на сучасну людину, відбувається динамічне зростання кількості патологій опорно-рухового апарату. Слід визнати той факт, що попри безперечні досягнення медицина залишається безсилою перед зростанням рівня захворюваності.

Однією з причин такої ситуації є беззастережна орієнтація медицини на лікування симптомів захворювання, при цьому ігноруючи їх причини. Таке симптоматичне лікування не вирішує механічні проблеми, пов'язані з кістково-м'язовим дисбалансом, зміщенням хребців, порушенням рухливості, кровопостачання або іннервації органів тощо. Крім цього, залишається незадіяним величезний потенціал кінезитерапії в комплексі з кінезіологією, у яких закладені принципи холістичної медицини.

У рамках даного дослідження під терміном «кінезитерапія» (лат. kinesis - pyx, therapia - лікування) слід розуміти вид терапії, спрямований на корекцію наявних патологій опорно-рухової системи (ОРС) шляхом виконання пацієнтом адаптованих і поступово наростаючих фрізичних навантажень, вид та інтенсивність яких визначається в індивідуальному порядку з урахуванням гіпо- та гіпертонічних м'язів і причини їх підвищеного або зниженого тонусу, типу захворювання, стадії, скарг хворого, його анамнезу, статі, віку, особливостей фрізіології тощо. Виконання цих навантажень у більшості випадків здійснюється за допомогою сучасних спеціальних тренажерів.

У цьому дослідженні термін «кінезіологія» (лат. kinesis - pyx, logos - наука) вживається в такому значенні: науково-практична дисципліна, що вивчає рухову фрункцію організму людини 3 метою діагностики причин фрормування порушень у кістково-м'язовій системі, їх корекції і відновлення повноцінної роботи організму. Вивчення м'язів і рухових розладів $\epsilon$ важливим насамперед тому, що на будь-яке захворювання організм людини реагує зміною збудливості м'язів і порушенням рухової функції.

Теоретичні та клінічні аспекти кінезитерапії, кінезіології та фрізичної реабілітації висвітлено в працях вітчизняних науковців і практиків, зокрема А. М. Лапутіна, В. О. Кашуби, В. В. Гамалія, О. А. Архипова, Т. О. Хабінець, М. О. Носко, О. К. Марченко, Т. Г. Рідковець, В. І. Козявкіна та багатьох інших. Високо оцінюючи значущість проведених досліджень і внесок вищеназваних авторів, які займалися дослідженням проблеми використання лікувальної фрізкультури та кінезіології в клінічній практиці, слід наголосити на необхідності подальшого поглибленого дослідження проблеми комплексного й інтегративного підходу з метою створення дієвого інструментарію, який забезпечить ефективну відновну терапію, реабілітацію та профрілактику захворювань опорно-рухового апарату. Інтегративний підхід забезпечує вплив на причину хвороби, а не на іiї наслідок. При цьому відбувається відновлення всього організму хворого, а не позбавлення від одного конкретного захворювання.

Мета та завдання дослідження. Метою дослідження визначено розроблення Системи інтегративної кінезитерапії (СІК) відновлення здоров'я, реабілітації та профілактики захворювань опорно-рухового апарату на принципах інтегративної медицини.

Для реалізації цієї мети було сформульовано такі завдання:

- систематизувати, узагальнити, розробити теоретико-практичні засади СІК на основі синтезу сучасних нефармакологічних методів кінезіології та кінезитерапії: кінезіологічної діагностики і корекції, кінезитерапевтичного впливу;

- систематизувати, узагальнити, розробити принципи формування кінезитерапевтичних програм з урахуванням кінезіологічної діагностики і корекції.

Методи дослідження: аналіз, узагальнення, синтез і систематизація.

Результати дослідження. На сьогодні в Україні досить динамічно розпочався процес клінічного використання кінезитерапевтичних методів для реабілітації та лікування захворювань кістково-м'язової системи. Діючі методи кінезитерапії мають свої плюси і мінуси, більшою чи меншою мірою ефективні у різних ситуаціях.

Так, В. І. Козявкін [9] створив методику, у якій сформульовано основи коригування рухових порушень у дітей з ДЦП. Ним створено систему інтенсивної нейрофрізіологічної реабілітації, кінцева мета якої полягає у підвищенні якості життя хворої дитини, що $є$ найважливішою соціально значущою проблемою сучасної відновлювальної медицини. Автор встановив роль перисреричного вертеброгенного компоненту поряд з ураженням 
структур мозку у дітей з ДЦП. Його авторська методика біомеханічної корекції хребта $є$ досить прогресивною.

В. І. Дікуль створив методику реабілітації при захворюваннях опорно-рухового апарату [8], яка грунтується на використанні кінезитерапії і спеціальних тренажерів. Важливим елементом лікування $€$ система вправ 3 вольової саморегуляції людини. Автор виходить з того, що однією з умов успішного відновлення $\epsilon$ сила волі, віра, бажання і сила думки.

Методика С. М. Бубновського [1] схожа на методику В. І. Дікуля стосовно кінезитерапевтичного впливу на організм пацієнта. Ця методика дає змогу розробити індивідуальну кінезитерапевтичну програму відновлення за допомогою спеціальних тренажерів.

Методика В. В. Євмінова [патент РФ № 2242207] розроблена з метою запуску механізмів самовідновлення структур хребта шляхом створення для цього необхідних умов: поєднання дозованого витягнення (розвантаження) хребта й одночасного спрямованого тренінгу глибоких м'язів спини. 3 метою витягнення використовується профрілактор Євмінова.

На нашу думку, більш успішними $€$ методи, в яких використовуються фрізичні вправи з обтяженнями на силових тренажерах. Як показали численні дослідження, у разі використання фрізичних вправ з обтяженнями найбільш ефективно відбувається фоормування м'язової тканини, ліквідація ії десріциту, i, відповідно, десріциту ії корсетної, гіподинамічної та метаболічної фуннкцій [1].

Спільними ознаками розглянутих методів $\epsilon$ відновлення нормальної роботи м'язів і кістковом'язової системи в цілому шляхом виконання спеціальних фрізичних вправ. Однак, ці методи не забезпечують необхідної ефективності, оскількі вузько діють на патогенез розвитку захворювання. У процесі їх застосування часто відбувається вплив не на причину змін в опорно-руховому апараті, а на наслідок цих змін - патологію суглоба / хребта (больовий гіпертонус м'язів, остеохондроз, артроз, сколіоз тощо).

Так, у багатьох розглянутих підходах пропонується однакова схема відновлення здоров'я, реабілітації та профілактики для всіх хворих 3 однаковим діагнозом. Справа в тому, що одне й те саме захворювання характеризується різною індивідуальною складовою м'язової і суглобової диссрункції. Саме тому у процесі реабілітаційно-відновних заходів стратегічно важливим $\epsilon$ пошук причини функціональної слабкості м'язів, залучення до руху ослаблених м'язів, робота 3 усунення перенавантаження м'язів, які працюють надмірно, що найчастіше спричинює відчуття болю. Перевантажені м'язи коротшають, призводячи до порушення й обмеження рухомості суглоба, формуючи відчуття болю. А оскільки до процесу компенсаторно можуть залучатися різні м'язи, то можливою $є$ міграція болю. Все це свідчить про те, що усунення м'язового дисбалансу в різних пацієнтів - це індивідуалізований процес, а тому персоніфікованими мають бути схеми реабілітації та відновлення і комплекси фрізичних вправ.

Часто буває так, що фрахівець, оглянувши місце, де хворий відчуває біль, виявляє спазмовані м'язи i, не задумуючись про причину болю, призначає вправи на їх розтягнення, сподіваючись, що позбавить пацієнта болю. Інколи це вдається, а частіше - ні [4].

Методика С. М. Бубновського допускає виконання вправ на фоні больових відчуттів. Ми вважаємо, що не варто вдаватися до виконання вправ через біль, тому що за законами кінезіології не можна тренувати болючий м'яз. Якщо правильно виконувати рух, біль повинен зникнути. Якщо на фоні болю продовжувати виконувати вправу, то це буде оголошенням війни своєму організму, яка завжди буде програна [7].

Таким чином, використання лише кінезитерапії у методиках відновлення, терапії та профілактики патологічних порушень має один суттєвий недолік. Він полягає у відсутності відповіді на такі питання: «Чи немає збою в правильній послідовності включення м'язів під час виконання руху? Які саме м'язи слід залучати у роботу?» А це призводить до того, що кінезитерапевтичний вплив може бути спрямованим не на причину хвороби, а на її наслідок.

Саме тому кінезитерапію мають доповнювати глибоке кінезіологічне дослідження та корекція, за допомогою яких визначаються м'язи, що не працюють, проводиться корекція їх роботи і лише після цього настає черга фрізичних вправ. Якщо проігнорувати етап кінезіологічної діагностики, то під час виконання програми кінезитерапії працювати будуть лише ті м'язи та м'язові групи, які $€$ найбільш натренованими та сильними. Слабкі м'язи, які і $\epsilon$ причиною патологічного стану, будуть залишатися незмінними, або, навпаки, - слабшати, що буде загострювати наявну дисорункцію.

Враховуючи вищевикладене, ключовим недоліком розглянутих методів $\epsilon$ відсутність взаємодії кінезіології та кінезитерапії в процесі їх практичного застосування для реабілітації та відновлення (нині кінезіологія i кінезитерапія 
значною мірою розвиваються незалежно одна від одної, що позначається на ефективності реабілітаційних заходів). Що стосується взаємодії кінезіології та кінезитерапії, то з цього приводу дуже влучно сказала профресор, доктор медичних наук, академік, завідувач кафедри мануальної терапії Першого Московського державного медичного університету ім. І. М. Сєченова, президент Асоціації прикладної кінезіології Росії Л. Ф. Васильєва: «Кінезіологія і кінезитерапія це різні і пов'язані етапи реабілітації м'язовоскелетної системи. Застосування кінезитерапії у відриві від кінезіології не дає можливості діагностувати збої в правильній послідовності включення м'язів у русі, який виконується. А якщо ця послідовність порушена, то під час виконання руху виникає не навантаження, а перевантаження місць прикріплення м'язів до суглобів хребта і кінцівок, їх зміщення з травматизацією міжхребцевого диска і внутрішньосуглобових елементів з подальшим посиленням больового синдрому. Саме такі пацієнти після проведення кінезитерапії надходять на хірургічне лікування» [4].

Отже, нині важливим $€$ завдання підвищення ефрективності відновлення здоров'я, реабілітації та профрілактики захворювань опорно-рухового апарату за рахунок комплексного підходу шляхом взаємодії кінезіології та кінезитерапії, розширення впливу на патогенез розвитку цих захворювань і розширення сорери використання методу, а саме для реабілітації та відновлення більшого кола захворювань.

Поставлена задача вирішується застосуванням Системи інтегративної кінезитерапії, яка об'єднала комплексну кінезіологічну діагностику, корекцію та кінезитерапевтичний вплив на організм пацієнта.

Система (методика) інтегративної кінезитерапії (СІК) - природно-біологічна, холістична методика відновлення здоров'я, реабілітації та профрілактики неврологічних, ортопедичних та інших захворювань, яка ґрунтується на систематизації й узагальненні досвіду різних напрямків медицини, об'єднанні комплексної кінезіологічної діагностики, корекції та кінезитерапевтичного впливу на пацієнта.

Таким чином, СІК являє собою цілісну методику відновлення функціонального стану опорнорухового апарату шляхом мобілізації внутрішніх резервів організму людини і поєднує в собі три складові: комплексну кінезіологічну діагностику та корекцію разом із кінезитерапевтичним впливом. Поетапне застосування цих трьох складових дає змогу провести ґрунтовне дослідження стану пацієнта, корекцію виявлених патологічних чинників і сорормувати оптимальний руховий стереотип для закріплення результату проведеної корекції [15, 16].

На першому етапі - етапі кінезіологічної діагностики - відбувається тестування функціональних можливостей рухового апарату, метою якого $€$ виявлення гіпо- та гіпертонічних м'язів та причини їх підвищеного або зниженого тонусу. Головним інструментом кінезіологічної діагностики є мануальне м'язове тестування (МMT), що проводиться у двох станах: спокою та функціонального навантаження.

Тестування починається із дослідження рухів: простих і складних. Спочатку діагностують якість простого руху, рух м'язів, що його виконують, збудливість м'яза, не задіяного у русі, далі - визначають ключові чинники, що сприяли зниженню адаптаційних можливостей м'язів. Після цього здійснюють ММТ із навантаженням (механічного, хімічного чи емоційного типу). Завершальною фразою цього етапу $є$ процес визначення реабілітаційного потенціалу пацієнта.

На другому етапі - етапі кінезіологічної корекції - відбувається ліквідація чинників, які сприяли виникненню порушень у роботі рухового апарату: запалення м'яза, зв'язки, патологічних процесів у внутрішніх органах, що здатні спричинити м'язову слабкість тощо.

Відновлення роботи м'яза відбувається шляхом застосування комбінації методик ішемічної компресії, мануальної терапії, кінезіологічного масажу, постізометричної релаксації, кінезитерапії тощо, після чого відбувається відновлення руху, який виконував пошкоджений м'яз: рух без застосування опору зі сторони та з подоланням зовнішнього опору (пропріоцептивне нервовом'язове спрощення, або PNF).

На третьому етапі - етапі кінезитерапевтичного впливу - залежно від типу захворювання формується програма кінезитерапевтичної фріксації здійсненої корекції на базових і спеціальних багатофрункціональних тренажерах. 3 ії допомогою вдається закріпити оптимальний стереотип руху, зміцнити м'язовий корсет, поліпшити гіподинамічну та метаболічну функцію м'язів тощо.

Отже, загальний алгоритм процесу відновлення за СІК такий:

1. Діагностика функціонального стану м'язів.

2. У разі збереження активності рефлексу на розтягнення м'яза підбирають індивідуальну кінезитерапевтичну програму.

3. Якщо активність рефлексу на розтягнення м'яза знижена, то розпочинають процедуру кінезіологічної корекції з метою відновлення активності рефлексу на розтягнення. Після цього 
фрормують кінезитерапевтичну програму з метою закріплення відновленого рефлексу.

Кінезіологічна діагностика. Основна мета кінезіологічної діагностики - виявлення гіпотонічних м'язів і причини їх слабкості. Під час здійснення кінезіологічної діагностики забезпечується виконання двох завдань:

- локалізація хворого м'яза, що призвів до виникнення порушень тонусно-силового балансу м'язів;

- визначення причини недостатньої збудливості та гіпотонії хворого м'яза.

М'язова дисфункція $€$ основним наслідком будь-якого дисбалансу в організмі, через це аналіз пози і м'язове тестування $€$ першими і найінформативнішими методами дослідження. Враховуючи це, в Системі інтегративної кінезитерапії кінезіологічна діагностика включає такі етапи:

1. Опитування. Збирання скарг та анамнезу пацієнта допомагає виявити патологічні реакції регуляторних систем організму.

2. Візуальна оцінка невідповідності нормі статичного та динамічного стереотипу регіонального постурального м'язового дисбалансу.

3. Мануальне м'язове тестування, у процесі якого виявляють погіршення адаптаційних механізмів скелетних м'язів шляхом всебічного оцінювання фрункціональних властивостей м'яза, його здатності реагувати на збільшення опору та здійснення руху.

4. Мануальне м'язове тестування 3 терапевтичним навантаженням механічного, хімічного чи емоційного типу, що дає змогу віднайти причину зниження адаптаційних механізмів системи скелетних м'язів та визначити необхідний терапевтичний вплив: кінезитерапія, постізометрична релаксація, рефлексотерапія, мануальна терапія, гомеопатія та ін.

Мануальне м'язове тестування $€$ ключовим етапом кінезіологічної діагностики. Воно ґрунтується на принципах, сорормульованих академіком І. П. Павловим і профресором М. Р. Могендовичем:

- наявність функціонального зв'язку між скелетними м'язами та внутрішніми органами;

- дисорункція органа через нервову систему пов'язана з тонусом скелетних м'язів, які при захворюваннях внутрішніх органів стають слабкими.

Таким чином, ММТ - це діагностичний інструмент, який дозволяє ручним способом з використанням певних технік встановити біологічний зворотний зв'язок з тілом пацієнта, визначити тонус і силу м'язів, асоціативно пов'язаних з відповідними внутрішніми органами, хребцями й іншими структурами, і на цій основі абсолютно точно визначити причину розвитку того чи іншого захворювання.

Застосовуючи ММТ, можна з великою точністю оцінити функціональний стан людини, виявити різного роду дисбаланс в організмі, який часто пов'язаний не тільки з травмами, але й зі стресом, дисорункцією внутрішніх органів тощо.

Також ММТ дозволяє визначити індивідуальні особливості будови і функціональності кістковом'язової системи, що дає можливість створити найбільш гармонійну та ефективну програму для кожного пацієнта, а значить - прискорити процес одужання і відновлення.

Різноманіття взаємного впливу між різними системами організму і скелетними м'язами в умовах наявної патології вже на фрункціональному рівні призводить до формування патологічних рефлексів, які, своєю чергою, проявляються у вигляді пригнічення активності рефллексу на розтягування скелетних м'язів і фрормування фрункціональної (зворотної) гіпотонії м'яза. Взаємовплив між різними системами організму і м'язами, що змінюють тонус, може бути механічного, хімічного й енергетичного походження. 3 цих позицій функціональна гіпотонія м'язів $€$ індикатором, що відображає патологію різних органів і систем організму, а тому її можна використовувати в діагностиці різних захворювань, і вона має прикладний характер.

Загальна схема мануального м’язового тестування така: м'язове тестування проводять у хворого, який перебуває у стані спокою у положенні сидячи, стоячи або лежачи. Залежно від м'яза, який тестується, тестований сегмент опорно-рухового апарату розміщують так, щоб м'язові волокна, які його утворюють, перебували на лінії скорочення і в нього мінімально включалися м'язи-синергісти:

1 фаза: хворий здійснює ізометричне скорочення м'яза, намагаючись зблизити місця його прикріплення проти адекватного опору руки або тулуба лікаря;

2 фраза: через 2,5-3 с за командою лікаря хворий намагається збільшити силу ізометричного напруження;

3 фаза: лікар здійснює короткочасне розтягування м'яза проти опору пацієнта, активізуючи виникнення міотатичного рефлексу (рефлексу на розтягування). Розтягування м'яза відбувається швидко, аналогічно розтягуванню сухожилля в разі удару неврологічного молоточка.

Критерії норми. У процесі ізометричного скорочення тонус м'яза поступово підвищується і в другій фразі збільшується на $15 \%$ норми. У 
випадку подальшого короткочасного розтягування сила скорочення м'яза суттєво збільшується від початкової норми (як результат активності реорлексу на розтягування).

Наявність здатності м'яза в умовах ізометричного навантаження підвищувати силу м'язового скорочення за рахунок збільшення м'язового тонусу і у відповідь на короткочасне розтягуванням відповідати активацією міотатичного рефлексу свідчить про можливість його адаптаційних механізмів і здатність розвивати силу, адекватну опору, що чиниться.

Функціональна м'язова гіпотонія - зниження адаптаційних можливостей скелетного м'яза, втрата його здатності збільшувати силу скорочення, адекватну опору, що чиниться, зниження його здатності адаптації до сили опору, що чиниться, або виконаному пасивному розтягуванню, як результат пригнічувального впливу зовнішніх або внутрішніх фракторів. М'яз несподівано стає нездатним до опору, «поступається» зусиллю дослідника, і кінцівка або руховий сегмент неначе «провалюється» [6].

Таким чином, м'язове тестування - це зворотний біологічний зв'язок з організмом хворого, використовуючи який лікар може вибрати серед великої кількості методів лікування та реабілітації ті, що допоможуть оптимально відновити фрункцію нервової і м'язової систем, а, отже, допоможуть запустити механізми самозцілення та самокорекції організму. Завдяки відновленню цих механізмів пацієнт впорається 3 хворобою сам.

Кінезіологічна корекція. На етапі, коли відбулося встановлення причини наявного порушення у роботі опорно-рухового апарату, складається детальний план реабілітаційно-відновних заходів. У тому разі, якщо причиною м'язової слабкості $€$ патологічний процес у внутрішніх органах, лікування починається 3 ліквідації цього процесу. Для цього застосовують такі методи лікування: гомеопатію, вісцеральну мануальну терапію, рефлексотерапію, дієтотерапію тощо.

Якщо м'язова слабкість зумовлена незадовільним психоемоційним станом пацієнта, терапію починають з нормалізації фрункціонування нервової системи.

Якщо причиною обмеження рухової активності $\epsilon$, власне, м'яз, то терапія починається $з$ відновлення його нормального функціонування.

Одну з провідних ролей у виборі методу міофрасціальної корекції відіграє процес точної локалізації м'язово-фрасціальних тригерних точок. Це ділянки скелетного м'яза, розташовані в ущільненому пучку із надзвичайно високим рівнем подразливості, схожому на надчутливий вузол, який можна відчути під час пальпації $[3,5]$.

Детальний опис міофасціальних тригерних точок можна знайти у праці Дж. Г. Тревелл і Д. Г. Сімонса «Міофрасціальні болі та дисфункції» [12]. На думку цих дослідників, тригерні точки $є$ результатом тривалого постійного навантаження на окремі м'язи. Ці надзбудливі ділянки, яким властиве локальне м'язове напруження, найчастіше розміщуються у скелетних м'язах і пов'язаних з ними фрасціях.

Хронічний спазм м'язів, формування тригерних точок, вкорочення та подовження м'язів 3 утворенням зрощень м'язів і фрасцій призводять до порушення кровообігу, лімфовідтоку та іннервації ураженої ділянки тканини. Виникає ригідність м'язової тканини і, як результат, - обмеження рухливості у даній зоні.

Залежно від локалізації міофасціальних тригерних точок методики корекції м'язовофасціальної патології можуть відрізнятися. Основними методами є: ішемічна компресія або масаж ділянки тригерних точок, міофасціальний реліз, розтягнення м'яза у поєднанні з перкусією, постізометрична релаксація, фрізичні вправи тощо.

Беручи це до уваги, можна виділити такі пріоритетні задачі Системи інтегративної кінезитерапії:

1. Відновлення природного стереотипу руху через пошук та корекцію причини його порушення - м'язової слабкості, яка розвинулася внаслідок:

- хвороби власне м'яза (виникнення тригерних точок, вкорочення фрасції);

- затиснення нервового закінчення, що іннервує м'язове волокно;

- надмірної активності допоміжних м'язів, які, беручи участь у русі, пригнічують активність головного м'яза;

- хвороби внутрішнього органа, яка здійснює асоціативний вплив на функціональний стан м'яза.

2. Відновлення м'язової сили шляхом усунення причини його пошкодження, поновлення ролі м'яза у здійсненні руху та формуванні здорового рухового стереотипу.

Таким чином, відновлення оптимального стереотипу руху дає можливість налаштувати роботу аферентних (від периферії до центру) сигналів від структур опорно-рухового апарату та навіть внутрішніх органів, що впливають на переміщення тіла у просторі, а також сформувати правильні зворотні сигнали (від мозку до периферичних нервових закінчень). 
Після відновлення фрункції м'язів необхідно створити умови для відновлення тонусу і сили м'язового волокна, а також зв'язку «ЦНС - орган - ЦНС». На цьому етапі застосування саме кінезитерапії матиме позитивний вплив.

При тривалому (не менше 3 тиж.) тренуванні м'язи приходять у свій нормальний тонус - фрізіологічний стан і здатні утримувати тіло у правильному і вигідному, а головне - здоровому положенні. Для підтримання оздоровчого ефекту необхідно з певною частотою (хоча 61 раз на тиждень) виконувати фрізичні вправи з метою навантаження важливих для постави і руху м'язів.

Слід зауважити, що описаний алгоритм роботи Системи інтегративної кінезитерапії можна ефективно використовувати для оцінки готовності організму спортсмена до ефективного виконання поставлених тренувально-змагальних завдань. Тобто в процесі мануального м'язового тренування можна оцінити активність рефлексів руху конкретних м'язів під час виконання тих чи інших дій, а в разі зниження активності рефрлексу руху - визначити причину виявлених порушень, обрати метод корекції і запропонувати методику перенавчання з метою оптимізації виконуваних професійних рухів.

Базові принципи формування кінезитерапевтичної програми. Під терміном «кінезитерапевтична програма» розуміють комплекс індивідуально підібраних фрізичних вправ, виконання яких забезпечує стійкий відновно-реабілітаційний ефрект за рахунок відновлення функціональності пошкоджених м'язів і функцій опорно-рухового апарату. У процесі виконання фрізичних вправ відбувається тренування скелетної мускулатури, що забезпечує зміцнення «м'язового корсета», виведення м'язів зі спазмованого стану, включення в роботу ослаблених м'язів і нормалізацію живлення суглобових тканин і хребта, і найголовніше - фрормування здорового (оптимального) рухового стереотипу.

Основу такої програми становлять фрізичні вправи з обтяженнями, що виконуються на спеціальних тренажерах, які мають декомпресійний компонент. Для складання оптимальної програми кінезитерапії насамперед враховують результати кінезіологічної діагностики, проблему закріплення простого патерну руху та відновлення загального (складного) патерну руху, крім цього беруть до уваги фрізичний стан пацієнта, тяжкість захворювання, наявність супутніх патологій, а також структурні та фрункціональні основи взаємодії м'язів при різних положеннях і рухах тіла, відображені у динамічній анатомії та біомеханіці.
Важливо розуміти, що для здійснення того чи іншого руху м'язи залучаються до м'язових пар, спіралей та поздовжніх м'язових з'єднань, що дає можливість кожному м'язу працювати злагоджено. У виконанні руху найважливішу роль відіграють саме м'язові спіралі, адже вони залучають м'язи з обох сторін тіла, об'єднуючи таким чином праву та ліву його половини та забезпечуючи збереження білатеральної симетрії тіла, а значить нормальної постави в умовах гравітації.

Інше значення м'язових спіралей полягає в тому, що вони $€$ природними амортизаторами, які пом'якшують поштовхи тіла під час переміщення у просторі. Також завдяки їм відбувається перехресна координація роботи верхніх і нижніх кінцівок під час пересування.

Так, відповідно до теорії міофрасціальних меридіанів Т. Майєрса, жоден м'яз не працює відокремлено, під час виконання рухів вони функціонально об'єднуються в міофасціальні меридіани, які $\epsilon$ унікальною картою фасціальних зв'язків через м'язи, сухожилля і фрасції, знання яких відкриває нові горизонти розуміння взаємозв'язків у тілі і веде до нових терапевтичних стратегій. Іншими словами, міофрасціальні меридіани є сполученнями фасцій і кісток, що обвивають все наше тіло, з'єднуючи голову з пальцями ніг, i управляють гравітаційними силами і м'язовим рухом, які потрібні для підтримання стабільності або для руху.

Таким чином, у процесі розроблення кінезитерапевтичної програми важливу роль відіграє знання фосціальних з'єднань і фрункцій м'язів, представлених Т. Майєрсом. Це допомагає підібрати найкращий метод корекції для конкретного пацієнта. Наприклад, впливаючи на міофасціальний дисбаланс нижнього відділу ноги, можна вплинути на фрункцію ребер і механіку хребта. Всі фасції і м'язи в організмі нерозривно пов'язані між собою, окремо взятий м'яз хоч і виконує своє завдання, але працює всередині міофасціальних пластів (ланцюгів, ліній). Усі м'язи і фрасції утворюють єдиний міофасціальний футляр. Усі м'язи тіла розділені на фасціальні кишені, яких налічується більше 600 [11].

$\mathrm{He}$ маючи уявлення про міофасціальні з'єднання, можна не помітити фракторів, що закріплюють ту чи іншу модель руху, яка знижує успішність реабілітації або взагалі порушує процес лікування. Все це свідчить про важливість знання і розуміння фрасціальних з'єднань і фрункцій м'язів для встановлення правильного діагнозу, а отже, й ефективного лікування.

Кінезитерапевтична програма має передбачати поступове наростання силового впливу через 
спеціальні фрізичні вправи, що підібрані та адаптовані конкретно для кожного організму. Як вже зазначалося, персоналізації програми вдається досягти завдяки проведенню повного мануального м'язового тестування, вивченню анатомічних, фізіологічних, вікових та інших особливостей пацієнта, ретельному запису анамнезу.

Поетапний та послідовний підхід, що застосовується у програмі відновлення, реабілітації та профрілактики, забезпечує поступове навчання скелетно-м'язового апарату пацієнта правильним простим і складним рухам, які з часом закріплюються на рефрлекторному рівні, фоормуючи руховий стереотип. Паралельно з цим відбувається відновлення еластичності та скоротливості м'язів, нормалізація обміну речовин у структурах рухового апарату, що перебували у патологічному стані. Потім поступово налагоджується процес трофріки тканин суглоба, що проявляється поліпшенням рухливості, зменшенням болю та запалення.

Підсумовуючи вищевикладене, можна зробити висновок, що реабілітація та профілактика за допомогою Системи інтегративної кінезитерапії базується на відновленні фрункціональності пошкоджених м'язів, тому що саме вони $є$ причиною утворення фрункціональних блокад, зниження рухливості суглобів і початку дистрофрічних змін у суглобовому хрящі. На відміну від інших відновно-реабілітаційних методів, СІК першочергово спрямована на терапію м'язів, а не на терапію суглобів і хребта, які, насправді, $\epsilon$ результатом, а не причиною хвороби.

У процесі розроблення кінезитерапевтичної програми слід враховувати безліч різноманітних чинників, серед яких виділяють наступні:

1. Індивідуальний підхід. Для кожного хворого розробляється індивідуальна кінезитерапевтича програма $з$ урахуванням його можливостей, супутніх патологій, давності захворювання, діагнозу, поставленого під час реалізації першого етапу, методу інтегративної кінезитерапії та результатів формування оптимального рухового стереотипу на другому етапі.

2. Декомпресійність фоізичних вправ. Декомпресійність вправ полягає в тому, що при їх виконанні мінімізується контакт поверхонь суглобів за рахунок механізму витягування, що дозволяє уникнути стиснення хрящів і дає можливість працювати тільки м'язам.

3. Антиграßітаційність впраß. Антигравітаційні вправи - це вправи в підвішеному стані, коли тулуб або кінцівки висять у повітрі і завдяки цьому досягається максимальне розвантаження суглобів і витягування м'язів і зв'язок.
4. Загальна Взаємозалежність м'язовофосиіальної системи. Під час виконання рухів жоден м'яз не працює відокремлено. М'язи функціонально об'єднуються в м'язові пари, поздовжні м'язові з'єднання і м'язові спіралі, що забезпечують узгодженість їх роботи.

5. Цілісний $і$ комплексний підхід. Програма лікувальних сеансів має включати як вправи для «проблемного» регіону, так і вправи для інших груп суглобів з урахуванням наявних м'язових дисбалансів. Крім того, слід звернути особливу увагу на відновлення оптимального рухового стереотипу і постави (здатність «ставити» тіло правильно). Програма укладається 3 урахуванням впливу на причину патології, а не ії наслідок.

6. Поступовий підxід. Ваги і обсяг навантаження підбирають на тестовому занятті індивідуально. В свою чергу, програма складається послідовно від простих вправ до більш складних у виконанні. Навантаження в розрізі вправ збільшується поступово як за обсягом, так і за інтенсивністю. Спочатку збільшується обсяг: кількість повторень вправ, підходів (не більше 3), згодом наростає інтенсивність. Під час перших 2-3 занять нового комплексу акцент робиться на техніці виконання, диханні (2-3 заняття) і розумінні сенсу рухового завдання.

7. Змічнення постуральних м'язіВ. При захворюваннях суглобів і хребта особливу увагу приділяють роботі $з$ м'язами, які $\epsilon$ найкращим фріксатором суглобів і хребців.

8. Відновлення коротких (глибоких) м'язів хребта. 3 огляду на роль коротких м'язів як стабілізаторів хребців під час руху кінцівками в процесі розробки до кінезитерапевтичних програм необхідно включати вправи, орієнтовані на зміцнення цих м'язів. Цього можна досягти за рахунок включення до програми вправ із використанням балансувальних платформ.

Отже, з упевненістю можна стверджувати, що успіх відновлення здоров'я з використанням Системи інтегративної кінезитерапії повною мірою залежить від якості проведеної діагностики, корекції та ефрективності розробленої індивідуальної кінезитерапевтичної програми.

Система інтегративної кінезитерапії має широкий спектр показань, довела свою ефективність при відновленні, реабілітації та профілактиці багатьох захворювань як опорно-рухового та нервового апаратів, так і хронічних захворювань серцево-судинної, ендокринної, травної та дихальної систем. Крім цього, слід зазначити незначну кількість протипоказань. Серед основних протипоказань можна виділити: гострі запальні та інфекційні захворювання; тромбози, емболії; 
кровотечі та схильність до них; злоякісні новоутворення; виражену недостатність будь-якої системи органів.

\section{Висновки.}

1. Філософрія методу інтегративної кінезитерапії базується на двох основних принципах. Головний принцип кінезіології полягає в тому, що захворювання позначається на м'язах; кінезитерапія грунтується на твердженні, що рух це життя. Справді, будь-яке захворювання позначається на м'язах - якщо орган $є$ здоровим, то м'яз працює в нормальному тонусі, а якщо в роботі органа стається збій, тонус відповідного м'яза слабшає. Тому стратегічно важливим у процесі відновлення здоров'я 3 використанням CIK $\epsilon$ пошук причини фрункціональної слабкості м'язів, залучення до руху ослаблених м'язів, робота з усунення перенавантаження м'язів, які працюють надмірно, що найчастіше спричинює відчуття болю.

2. СІК лікує не наслідок хвороби, а її причину. Мануальне м'язове тестування дає змогу встановити причину патології і визначити методи іiї корекції. За результатами розробляється кінезитерапевтична програма, яка забезпечує фрормування оптимального рухового стереотипу і зміцнення кістково-м'язової системи. Важливим $\epsilon$ те, що в процесі ММТ причина захворювання може бути виявлена на ранніх стадіях, коли вона лише зароджується на рівні функціональних дисбалансів у системах і органах людини. Знання причини ще на доклінічному етапі дає можливість усунути іiі і тим самим запобігти захворюванню.

3. Захворювання ОРС мають біометричний характер. Це означає, що неправильний рух і механічні недоліки в опорно-руховій системі 3 часом спричинюють біохімічні зміни у суглобах і їх повне руйнування. Таким чином, якщо м'яз чи група м'язів з якої-небудь причини діють неефективно, то виникають дисбаланс і нестабільність руху, що врешті-решт призводить до захворювань опорно-рухового апарату.

4. Кінезитерапія застосовується лише за результатами ММТ. Враховуючи сучасні умови життя, складно знайти людину, в якої відсутній кістковом'язовий дисбаланс. Це наслідки і гіподинамії, і тривалого перебування в одній позі, і циклічних

\section{Література}

1. Бубновский С. М. Практическое руководство по кинезитерапии / С. М. Бубновский. - М. : Астрея-центр, 1998. - 104 с.

2. Бубновский С. М. Профилактика заболеваний костно-мышечной системы у школьников средствами кинезитерапии: автореф. дисс. ... канд. мед. наук [Электронный навантажень тощо. Водночас важливо розуміти, що хронічні невиявлені хвороби внутрішніх органів також призводять до слабкості м'язів, обмеження рухливості в суглобах і хребті і, звичайно ж, до фрормування м'язового дисбалансу.

У такому випадку активні заняття спортом або фрізкультурою будуть лише поглиблювати його: непрацюючі м'язи напружуватися не будуть, а м'язи, які виконують компенсаторну фрункцію, будуть ще більше перевантаженими.

5. У процесі формування кінезитерапевтичної програми ставиться мета - відновити постуральний м'язовий баланс та оптимальний руховий стереотип для нормалізації фуннццій усіх систем організму пацієнта.

6. Впроваджено новий принцип фоормування кінезитерапевтичної програми на основі аналізу балансу м'язових ланцюгів тіла та їх впливу на постуральний дисбаланс.

7. Кінезитерапевтична програма складається 3 акцентом на функціональний стан м'язів, а не на структурні зміни, які $\epsilon$ результатом порушень у нервово-м'язових взаємозв'язках.

8. У рамках СІК було створено чіткі теоретико-практичні засади відновлення здоров'я, реабілітації та профрілактики неврологічних та ортопедичних захворювань. У роботі здійснено систематизацію і узагальнення методів діагностики захворювань кістково-м'язової системи, прийомів корекції простого рухового стереотипу, фрізичних вправ корекції складного рухового стереотипу та ффізичних вправ відновлення тонусу i сили м'язового волокна. Було встановлено чіткі показання до їх застосування.

9. СІК дає можливість виявити приховані рухові резерви організму спортсмена і запропонувати механізми перенавчання 3 метою оптимізації виконуваних професійних рухів.

Перспективи подальших досліджень у даному напрямку пов'язані з розширенням сорери використання СІК, а саме для відновлення здоров'я при ширшому колі захворювань. Також перспективними $€$ подальші дослідження, пов'язані 3 виявленням прихованих рухових резервів організму, і розроблення ефективних механізмів перенавчання $з$ метою оптимізації виконуваних профеесійних рухів.

\section{References}

1. Bubnovskyy S. M. (1998) Practical Guide to kinesitherapy. Moscow: Center Astrea. (in Russian)

2. Bubnovskyy S. M. Autoabstract of master's dissertation on a topic "Prevention of diseases osteo-muscles system in schoolchildren by means of kinesitherapy" Access: http://www.dissercat.com/content/profilaktika-zabolevanii- 
pecypc] / С. М. Бубновский. - Режим доступа : http:// www.dissercat.com/content/profilaktika-zabolevanii-kostnomyshechnoi-sistemy-u-shkolnikov-sredstvami-kineziterapii.

3. ВасильеВа Л. Ф. Визуальная и кинезиологическая диагностика патобиомеханических изменений мышечно-скелетной системы / Л. Ф. Васильева. - М. : Роликс, 2012. - 108 с.

4. ВасильеВа Л. Ф. Прикладная кинезиология [Электронный ресурс] / Л. Ф. Васильева. - Режим доступа : http://massage21.org/prikladnaya-kineziologiya.-statyaprofessora-vasilevoj-l.f

5. ВасильеЪа Л. Ф. Прикладная кинезиология в спорте высших достижений: метод. рек. / Л. Ф. Васильева. - М. : Скайпринт, 2013. - 104 с.

6. ВасильеВа Л. Ф. Теоретические основы прикладной кинезиологии / Л. Ф. Васильева. - М. : ВИС, 2003. - 83 с.

7. Bucmyn на телебаченні професора, доктора медичних наук Л. Ф. Васильєвої [Електронний ресурс] /Л. Ф. Васильєва. - Режим доступу : http://www.conspekt.info/ pluss0912/6964818747.

8. Дикуль В. И. Против боли в суставах / В. И. Дикуль. - М. : Эксмо, 2012. - 272 с.

9. КозяВкин В. И. Основы реабилитации двигательных нарушений по методу Козявкина / В. И. Козявкин, Н. Н. Сак, О. А. Качмар, М. А. Бабадаглы. - Львов: НВФ и Укр. технологии, 2007. - 191 с.

10. ЛікуВання артрозу великих суглобів способом інтегративної кінезитерапії [Електронний ресурс]. - Режим доступу : http://uapatents.com/27-91441-likuvannyaartrozu-velikikh-suglobiv-sposobom-integrativno-kineziterapi. html

11. Майерс Т. Анатомические поезда. Миофасциальные меридианы для мануальной спортивной медицины / Т. Майерс. - М. : Меридиан-С, 2012. - 320 с.

12. Симонс Д. Г. Миофрасциальные боли и дисфрункции : рук. по триггерным точкам : в 2 т. / Д. Г. Симонс, Ж. Г. Тревелл, Л. С. Симонс; пер. с англ. - 2-е изд. перераб. и дополн. - М. : Медицина, 2005. - Т. 1. - 1192 с.

13. Спосіб лікування гриж міжхребцевих дисків [Електронний ресурс]. - Режим доступу : http://uapatents.com/ 25-90670-sposib-likuvannya-grizh-mizhkhrebcevikh-diskiv.html

14. Спосіб лікування захворювань опорно-рухового апарата [Електронний ресурс]. - Режим доступу : http://uapatents. com/39-90674-sposib-likuvannya-zakhvoryuvan-oporno-rukhovogo-aparata.html

15. Спосіб лікування плечолопаткового періартриту [Електронний ресурс]. - Режим доступу : http://uapatents. com /26-90673-sposib-likuvannya-plecholopatkovogo-periartritu.html

16. Спосіб лікування поперекового остеохондрозу 3 грижами дисків [Електронний ресурс]. - Режим доступу : http:/ / uapatents.com /25-90672-sposib-likuvannya-poperekovogo-osteokhondrozu-z-grizhami-diskiv.html

17. Спосіб лікування шийного остеохондрозу [Електронний ресурс]. - Режим доступу : http://uapatents. com/25-90671-sposib-likuvannya-shijjnogo-osteokhondrozu. $\mathrm{html}$

bogdan kravchenko@hotmail.com

\section{Спортивна медицина і фізична реабілітація, №2, 2016}

kostno-myshechnoi-sistemy-u-shkolnikov-sredstvami-kineziterapii (in Russian)

3. Vasilieva L. F. (2012) Visual and kinesiology diagnostic of pathobiomechanic changes of skeletomuscular system. Moscow: «Rolyks» (in Russian)

4. Vasilyeva L. F. (2014) Applied kynesiology [Electron resource] Access: http://massage21.org/prikladnayakineziologiya.-statya-professora-vasilevoj-l.f (in Russian)

5. Vasilyeva L. F. (2013) Applied kinesiology in the high performance sport. Guidelines. Moscow: «Skayprynt» (in Russian)

6. Vasilieva L. F. (2003) Theoretical foundation of Applied Kynezyology. Moscow: «ВИС» (in Russian)

7. Vasiliev L. F. (2014) TV appearance of Professor L. F. Vasilieva [Electron resource] Access: http://www.conspekt.info/pluss0912/6964818747. (in Ukrainian)

8. Dikul V. I. (2012) Against the joint pain. Moscow: Eksmo (in Russian)

9. Kozyavkin V. I., Sak N. N., Kachmar A. A., Babadahly M. A. (2007) Principles of Rehabilitation of movement disorder by the Kozyavkin's method. L.: SPC and Ukr. tehnolohyy (in Russian)

10. Treatment of osteoarthritis of large joints by means of integrative kinesitherapy - http://uapatents.com/2791441-likuvannya-artrozu-velikikh-suglobiv-sposobom-integrativno-kineziterapi.html (in Ukrainian)

11. Myers T. (2012) Anatomical train. Myofascial meridians for manual sport medicine. Moscow: «Meridian-S» (in Russian)

12. Symons D. G., Trevell Zh. H., Symons L. S. (2005) Myofascial pain and dysfunction: Guidance to trigger points. 2nd edition revised and updated. Moscow: Medicine, Vol. 1. (in Russian)

13. A method of spinal disc herniation treatment http:/ / uapatents.com /25-90670-sposib-likuvannya-grizhmizhkhrebcevikh-diskiv.html (in Russian)

14. A method of musculoskeletal system disorders treatment - http://uapatents.com/39-90674-sposib-likuvannyazakhvoryuvan-oporno-rukhovogo-aparata.html (in Ukrainian)

15. A method of scapulohumeral periarthritis treatment - http://uapatents.com/26-90673-sposib-likuvannyaplecholopatkovogo-periartritu.html (in Ukrainian)

16. A method of treatment of lumbar osteochondrosis with spinal disc herniation - http://uapatents.com/2590672-sposib-likuvannya-poperekovogo-osteokhondrozu-zgrizhami-diskiv.html (in Ukrainian)

17. A method for cervical osteochondrosis treatment http://uapatents.com/25-90671-sposib-likuvannya-shijjnogoosteokhondrozu.html (in Ukrainian) 